JMKSP (Jurnal Manajemen, Kepemimpinan, dan Supervisi Pendidikan) Volume 6 Issue 2 (2021) Page 200-213

ISSN 2614-8021 (Online) 2548-7094 (Print)

\title{
Implementation of School Problem Solving Management in Improving School Achievement
}

\section{Asep Suparman ${ }^{1}$, Rambat Nur Sasongko ${ }^{2}$, Muhammad Kristiawan ${ }^{3}$ ${ }_{1,2,3}$ Universitas Bengkulu}

Corresponding Author E-mail: suparmanasep102@gmail.com

Received 22 April 2021; Revised 30 April 2021; Accepted 3 May 2021

\begin{abstract}
This qualitative study described the innovation regarding the application of principal problem solving management to improve school achievement. The results showed that the application of principal problem solving management can improve school achievement characterized by the number of awards received by schools, increased public interest and the existence of other schools that have comparative studies to school. The innovation of principal managerial dealing with various kinds of complex problems will be able to improve school achievement.
\end{abstract}

Keyword: School Problem Solving Management, School Achievement, Principal

\section{Introduction}

The principal is required to improve the quality of the school he leads. Meanwhile, every school has different problems and some are even complex. Leading a school that has a majority of students who come from weak economies and academically do not require proper decision making by principals, so as to improve school achievement. 
Danim (2012) argues that progress and improvement in school achievement are often determined by the capabilities of the principal in addition to the presence of competent teachers in the school. In line with this statement, Irwanto \& Arifin (2020) and Subaidi (2020) said that the existence of the principal is a central figure who can change the face of an education unit or school, whether for better or worse over time. In relation to school performance or student achievement at school, Tiswarni (2019); Triwiyanto, (2013) states that school effectiveness, most student achievement is influenced by the quality of school management. This means that the role and function of the principal is so important in an effort to improve the achievement of the school he leads. The novelty in this study is different from previous research, because it can provide solutions to every problem faced at school. The contribution of this research is in the field of educational administration management, especially for school principals.

\section{Methods}

The method used in this research was descriptive qualitative. The instruments used in data collection were: (1) learning logs, (2) testimonials, (3) interviews, (4) documentation from school archives, and photos. The research subjects were teachers, school supervisors and school committees at Public Vocational High School 3 Rejang Lebong. Interviews were carried out in stages starting from the school academic community, teachers, school officials, students and graduate users. This is done to complete the various kinds of data needed during the research. Qualitative descriptive method describes the situation and condition of the research domain that occurs with descriptions of words and from documentation (Hermawan, 2015; Purnomo, 2014; Putri \& Citra, 2019; Saripudin \& Faujiah, 2018; Syaputra, 2019).

\section{Results and Discussion}

To be able to see any changes after implementing the principal's problem solving management in improving school achievement, it is necessary to describe the initial conditions before implementing problem solving management at Public Vocational High School 3 Rejang Lebong. First, data sources on the state of 
infrastructure and facilities at Public Vocational High School 3 Rejang Lebong in February 2014 that: (1) there are only 9 classrooms; (2) there are only 3 student practice rooms; (3) inadequate number of student desks; (4) insufficient practical equipment; (5) sports equipment is still inadequate. Then the state of the number of students, before implementing problem solving management: (1) the number of students in grade 10, grade 11, grade 12 has a total of only 98 students; (2) the total number of new student admissions is only 23 people for 3 skill competencies in grade 10. Furthermore, the state of the number of skills competencies: there are 3 skill competencies, fishery agribusiness, poultry agribusiness and computer and network engineering.

Other conditions before the implementation of problem solving management were: (1) frequent student fights; (2) there are no graduates who work after graduating from school; (3) low teacher work ethic; (4) there is little cooperation network with the business world and the industrial world; (5) school achievement is still low.

Then after the principal has implemented problem solving management, starting from February 15, 2014 to the end of December 2019. The process of implementing problem solving management is carried out in the following steps: (1) the principal forms a school management team, consisting of: the principal, vice head of school, head of sub-division of school administration staff, head of expertise competency/head of department and head of the Internal Quality Assurance System; (2) problem solving in schools is carried out with problem solving procedures.

State data or final results, after implementing problem solving management from 2014 to 2018, it can be seen the fact that school performance is increasing, with various achievements starting in 2015 were One time regency level competition winner; champion of the provincial level competition twice and champion of the national level competition twice. Then in 2016, the school's achievements increased: two times regency level champion, four times provincial champion and two times national champion. Whereas in 2017 it increased again to 10 times regency level champion, 8 provincial level champion and 6 times 
national champion. In 2018, champion at district level 12 times, champion at provincial level 10 times and champion at national level 7 times.

Various achievements in the form of trophies, award certificates or medals as mentioned above can of course be achieved after the implementation of problem solving management programmed by the principal. Because the previous principal was established during the period March 2004 until January 2014, approximately 10 years since the school was founded, problem solving management has not been implemented. However, since the author was appointed as the principal of the school in mid-February 2014 to December 2019, almost 6 (six) years of problem solving management have been carried out, thank God, there have been changes in the form of increased school performance at Public Vocational High School 3 Rejang Lebong, Bengkulu Province.

Based on the results of the learning log entry and testimonials from students, teachers, school committees and school supervisors, the following data were obtained.

Grade 12 students Skills Competency: Pharmacy

Serlia Gustiani, learning log: Even though our school has limited facilities and the majority of us as students are not well off economically, thank God there are many students who make achievements in this school. 1st Winner of LKS Vocational High School in Fishery and Livestock from Bengkulu Province to National Level received the Superior Medal, 1st Winner of O2SN Gold Medal for Men and Women Karate Bengkulu Province so that they became O2SN Finalists for National Level Vocational High Schools, Became District and Provincial Paskibraka, 1st Place for Men's Team Walk and Putri Kemri Anniversary and many others

Teacher Islamic Religion, Vice Principal of Student

Sasmahera, learning log, our school is in the hamlet with limited facility and the majority of $4^{\text {th }}$ quadran students whose parents are economically disadvantaged and their students' academic abilities are lacking, but thank God many of our students who excel at this school, some are at the district, provincial 
level. and even National. So that with the school's many achievements, Public Vocational High School 3 Rejang Lebong is increasingly recognized by many parties, under the leadership of the school principal.

\section{School Committee}

Alfandie, learning log: since the principal of Public Vocational High School 3 Rejang Lebong, there have been many breakthroughs for school progress, including through the application of problem solving management, even though Public Vocational High School 3 Rejang Lebong facility is limited to land around $3,500 \mathrm{~m}^{2}$ and lack of building facilities, practice space, and also the majority of students here are categorized as having low academic and economic abilities of their parents, but they can still make teaching and learning activities run well and make various school achievements every year up to the national level, "so that because they have many achievements, the public's interest increases to send their children to Public Vocational High School 3 Rejang Lebong.

Superintendent of Vocational Schools, Education and Culture Office of Bengkulu Province

Azman Jayadi, learning log: the figure of a school principal with one-action strategy leadership towards a quality cultured school is very much needed in the present era, one of which is the Principal of Public Vocational High School 3 Rejang Lebong. With persistence in the midst of limited facility, but still able to compete with other vocational schools in Bengkulu Province. Because this school is interesting, even though the majority of students are categorized as weak academically and economically weak by their parents, but they have produced various proud achievements, both for their students and their school. In 2015 it received an award from the Minister of Education and Culture as a school that has integrity, then in 2016 it became the Model School for the Internal Quality Assurance System of Education Quality Assurance Agency Bengkulu. 2017 became a Model School for Strengthening Character Education.

After data collection was then processed, the results were as follows: learning $\log$ entries and testimonials, according to the opinion of Serlia Gustiani 
representing students, said even though our school is narrow and the majority of students are economically disadvantaged and academically deficient, thank God many students scored achievements in this school. First Place in the Fishery and Livestock Vocational School Student Competency Competition from the Bengkulu Province to the National Level received the Superior Medal, first place for the Gold Medal in the Men's and Women's Karate National Student Sports Olympiad at the Bengkulu Province Level so that they became Finalists for the National Student Sports Olympiad SMK Level National, to become Paskibraka Regency and Province, 1st place in men's and women's team trekking for the Independence Day of the Republic of Indonesia and many others.

This is reinforced by the opinion of Sasmahera, M.Pd, who represents the teacher, that: "even though our school is located in a hamlet with limited facilities and the majority of students are economically poor and their students' academic abilities are lacking, thank God many of our students are outstanding. in this school, there are those who excel at the district, provincial and even national levels. So that with the school's many achievements, Public Vocational High School 3 Rejang Lebong is increasingly recognized by many parties. Another evidence from the increasing recognition of many parties is the increasing public interest or trust to send their children to Public Vocational High School 3 Rejang Lebong Bengkulu Province.

This opinion was supported by the opinion of Alfandie as the head of the School Committee who said that the principal at Public Vocational High School 3 Rejang Lebong, there have been many innovative breakthroughs made for school progress, including through the application of problem solving management. So that the impact of this breakthrough innovation even though Public Vocational High School 3 Rejang Lebong has limited infrastructure and a narrow area of about 3,512 square meters and a lack of building facilities, practice space, and also the majority of students here are categorized as economically disadvantaged, but teaching and learning activities are running well and incised. various school achievements every year down to the national level, so that because they have many achievements, the public interest has increased to send their children to Public Vocational High School 3 Rejang Lebong, until the total number of 
students is more than 475 students, which was before the innovation of problem solving management was only 98 students.

Then Azman Jayadi as the school supervisor reinforced his previous opinion that: "the principal is persistent amidst limited sarpras, but is still able to compete with other Vocational High School in Bengkulu Province. Because this school is unique and interesting, even though the majority of its students are categorized as less academically and economically weak in their families, but it has produced a variety of proud achievements, both for the students and the school. In 2015 it received an award from the Minister of Education and Culture as a school with integrity, then in the last three years 2016, 2017 to 2018 it became the Internal Quality Assurance System Model School established by Education Quality Assurance Agency Bengkulu, so that this school has a quality culture, even in 2019 it became a reference school.

From the results of the collection of various achievements, this has led to an increase in public interest and confidence that as school achievement increases, the quality of the school also increases, when the quality of the school increases, the public's trust and interest increases so that the impact is as follows: (1) a total of 144 new students, from previously only 23 students; (2) previously there were only 3 (three) skill competencies, namely: Fishery Agribusiness, Poultry Agribusiness and Computer and Network Engineering. Now there are 6 (six) skill competencies, namely: Fishery Agribusiness, Poultry Agribusiness and Computer and Network Engineering, Welding Engineering, Motorcycle and Pharmaceutical Engineering; (3) the number of students in grade 10, grade 11, grade 12, a total of 475 students, from previously only 98 students; (4) there are only 9 classrooms, but a room use management system is made so that students can use it as a whole; (5) there are only 3 student practice rooms, with time settings for use: the number of student desks and chairs is adequate, practice equipment continues to be filled gradually, sports equipment is adequate, students are orderly, every morning there is a morning roll, the education system collaborates with Indonesian National Army and Police of Indonesian Republic in terms of strengthening character education, even carried out extracurricular pencak silat and karate so that achievement and student fights no longer exist. 
Other visible achievements are: (1) the Special Job Exchange has been running to take care of graduates who want to work, both domestically and abroad, in collaboration with PT. Mardel Anugerah International, Bright Education Bandung with the Ausbildung program (professional education program and apprenticeship in Germany) so that after graduating from school graduates can be ready to work; (2) the work ethic of teachers and education personnel increased from the previous low work ethic of teachers. Currently, there is a morning apple for teachers and education staff as well as fingerprint absences; (3) There are currently many collaborative networks with the Business and Industrial World, both for the purposes of placing field work practices or industrial work practices as well as for placing graduates to work in the world of work. Even in 2018 Public Vocational High School 3 Rejang Lebong was given job matching assistance by the Directorate of Vocational Education Ministry of Education and Culture; (4) The land area is only 3,512 m2. Currently, a proposal has been submitted to the Governor of Bengkulu through the Education and Culture Office of Bengkulu Province.

For a solution to the shortage of space, the following arrangements were made for student learning locations July - September $10^{\text {th }}$ grade students at the Yonif 144 / Jaya Yudha headquarters, $11^{\text {th }}$ and $12^{\text {th }}$ grade students at the school. Then in October - April grades 10 and 12 study at school, while grade 11 students practice fieldwork in business and industry. Furthermore, from May to June, grade 10 and 11 students study at school, while grade 12 students are preparing for graduation.

With the arrangement as mentioned above, although the limitations of sarpras do not interfere with the process of teaching and learning activities or practice according to the demands of the curriculum. This fact is admitted by Reppa et al., (2010) which illustrates that creative principals are able to create new programs, in the form of new activities such as research activities to improve the quality of education in schools and contests are able to improve teacher performance in improving school quality.

The increase in school achievement every year continues to increase, it can be seen in the following description: from 2004 to 2014, the principal's problem 
solving management has not been implemented. From February 15 to December 2014 (first year): (1) Starting from the author, he is entrusted with the noble position of the principal of the school; (2) Begin to organize school management through the implementation of problem solving management; (3) Establishment of a Management Team and work program; (4) Start implementing problem solving management.

In 2015 (the second year) the developments were (1) continued to implement a one-action strategy towards quality cultured schools; (2) obtaining 1st place LKS in Fishery field at Bengkulu Province Level; (3) getting $1^{\text {st }}$ place in LKS in Livestock at Bengkulu Province Level; (4) Obtaining a Charter of Appreciation from the Minister of Education and Culture of the Republic of Indonesia, regarding having a high integrity index in the implementation of the National Examination; (5) Collaborating with the soldier/police in fostering student character.

In 2016 (the third year) the development of school achievement is increasingly visible, as the following description (1) continue to apply the one action strategy towards a quality cultured school; (2) obtaining $1^{\text {st }}$ place LKS in Fishery field at Bengkulu Province Level; (3) Getting $1^{\text {st }}$ place in LKS in Livestock at Bengkulu Province Level; (4) Finalists for LKS National Level in Fishery and Livestock; (5) Becoming a ketarunaan school in collaboration with Kodim 0409/RL and Rejang Lebong Police; (6) Selected as a model school for the Internal Quality Assurance System by Education Quality Assurance Agency Bengkulu.

In 2017 (the fourth year), the peak of school achievement was as follows: (1) Obtaining $1^{\text {st }}$ place in Gold Medal at O2SN SMK in Men's Karate in Bengkulu Province Level; (2) Achieving 1st place in the Gold Medal at the O2SN Vocational High School in Women's Karate at the Bengkulu Province Level; (3) Becoming a National Level O2SN Vocational High School Vocational High School Finalist; (4) Becoming a ketarunaan school in collaboration with Kodim 0409/RL, Rejang Lebong Police and Infantry Battalion 144/Jaya Yudha; (5) Selected as a model school for the Internal Quality Assurance System by Education Quality Assurance Agency (LPMP) Bengkulu; (6) 2 students passed 
the Paskibraka selection for Rejang Lebong Regency and 1 person passed the Paskibraka selection for Bengkulu Province; (7) Obtaining $1^{\text {st }}$ place LKS in Fishery at Bengkulu Province Level; (8) Getting $1^{\text {st }}$ place in LKS in Livestock at Bengkulu Province Level; (9) Received a Superior Medal at the National Level LKS in the Fishery field; (10) Received a Superior Medal at the National Level LKS in the Livestock sector.

In 2018 (the fifth year), school performance has increased, as illustrated below (1) Becoming a school with skills in collaboration with Kodim 0409 / RL, Polres Rejang Lebong and Yonif 144/Jaya Yudha; (2) won $1^{\text {st }}$ place in the female high school level competition category at the Al-Azhar National Championship for the Martial Arts of Pencak Silat; (3) Obtained $1^{\text {st }}$ place LKS SMK Rejang Lebong Regency Level for IT/Networking Support; (4) Getting $1^{\text {st }}$ Place LKS SMK Rejang Lebong Regency Level Pharmacy Field; (5) Received $3{ }^{\text {rd }}$ Place LKS SMK Bengkulu Provincial Level for IT/Networking Support; (6) Getting $2^{\text {nd }}$ Place LKS Bengkulu Provincial Level SMK Pharmacy Field; (7) Obtaining $1^{\text {st }}$ place LKS in Fishery at Bengkulu Province Level; (8) Getting $1^{\text {st }}$ place in LKS in Livestock at Bengkulu Province Level; (9) Superior Medal of Minister of Education and Culture of National Level SMK LKS in Fishery field; (10) Finalists for LKS SMK National Level in Livestock sector. In addition to these achievements, there were additional achievements as follows: (1) The principal won second place in the National Level Vocational High School Principal Best Practice Competition; (2) First Place in the Vocational School Principal Election Competition Bengkulu Province; (3) Winner of the top 5 in the National Level Vocational School Head Election.

In 2019 (the sixth year) school achievement continued to increase, in addition to student achievement in each competition, the achievement of the principal also won third place in the non-fiction book writing competition about the experience of leading a school. Furthermore, in 2019 the school was designated as a reference school by the Directorate of Vocational Education, Directorate General of Primary and Secondary Education, Ministry of Education and Culture of the Republic of Indonesia. In addition, the school is designated as a target school for vocational revitalization by the Ministry of Education and Culture. Even in 2019 Dr. M. 
Bakhrun as the Director of SMK Development of the Ministry of Education and Culture attended Vocational High School 3 Rejang Lebong to open the opening ceremony for Batch VI Basic Personnel Training in Battalion 144/Jaya Yudha field. As well as opening the referral school activities at Public Vocational High School 3 Rejang Lebong. Problem solving management influences school achievement a lot (Ardiansyah \& Dardiri, 2019; Ekosiswoyo, 2016; Mohd Yusof et al., 2014; Tanjung et al., 2017; Zulkifli, 2014)

From the results of the collection of various achievements, it has led to increased school quality and public interest in sending their children to Public Vocational High School 3 Rejang Lebong. Thus, even though the school has many limitations, when the principal applies problem solving management it can improve school achievement.

\section{Conclusion}

Based on the results and discussion, it can be concluded that the application of principal problem solving management is proven to improve school achievement. It is proven that in 2015 Public Vocational High School 3 Rejang Lebong received an award certificate from the Minister of Education and Culture as a school that has a high integrity index in the implementation of the National Examination. Then in 2016 to 2018 it became a model school for the Internal Quality Assurance System assisted by the Bengkulu Province Education Quality Assurance Agency. In fact, in 2019 Public Vocational High School 3 Rejang Lebong was designated by the Ministry of Education and Culture to become a reference school and revitalization pilot school.

\section{Acknowledgement}

We would like to thank Drs. Eri Yulian Hidayat, M.Pd as Acting Head of Bengkulu Province Education and Culture Office who has motivated us to publish the results of this research. Mrs. Inne Kristanti, SP, M.Si as the Head of the Curup Region II Education Office Branch who has given us permission to conduct research on school managerial in Rejang Lebong. All teachers, educational staff, 
school committees, supervisors and students of Public Vocational High School 3 Rejang Lebong who have become respondents in this study.

\section{References}

Ardiansyah, L., \& Dardiri, A. (2019). Manajemen budaya sekolah berbasis pesantren di Madrasah Tsanawiyah Ali Maksum, Sewon, Bantul, Yogyakarta [Cultural management of a pesantren-based school at Madrasah Tsanawiyah Ali Maksum, Sewon, Bantul, Yogyakarta]. Jurnal Pembangunan Pendidikan: Fondasi Dan Aplikasi. https://doi.org/10.21831/jppfa.v6i1.22626

Danim, S. (2012). Kebijakan Pengembangan Profesi Guru. Materi Pendidikan dan Latihan Profesi Guru [Teacher Professional Development Policy. Teacher Professional Education and Training Materials]. Jakarta: Kementerian Pendidikan dan Kebudayaan.

Ekosiswoyo, R. (2016). Kepemimpinan Kepala Sekolah yang Efektif Kunci Pencapaian Kualitas Pendidikan [Effective Principal Leadership is the Key to Achieving Quality Education]. Jurnal Ilmu Pendidikan.

Hermawan, I. K. D. (2015). Kinerja Pendidikan Anak Usia Dini Dan Pendidikan Nonformal Berdasarkan Misi Pendidikan [Performance of Early Childhood Education and Nonformal Eduction Based on Education Mission]. Jurnal Pendidikan Dan Kebudayaan, 21(1), 87-100. https://doi.org/http://dx.doi.org/10.24832/jpnk.v21i1.178

Irwanto, I., \& Arifin, Z. (2020). Manajer Risiko: Peran Kepala MTS N 1 Kota Yogyakarta Dalam Pembelajaran Daring Masa Pandemi Covid-19 [Risk Manager: The Role of the Head of MTS N 1 Yogyakarta City in Online Learning during the Covid-19 Pandemic]. Tadbir: Jurnal Studi Manajemen Pendidikan, 4(2), 189-200.

Mohd Yusof, A., Daniel, E. G. S., Low, W. Y., \& Ab. Aziz, K. (2014). Teachers perception of mobile edutainment for special needs learners: The Malaysian case. International Journal of Inclusive Education, 18(12), 1237-1246. https://doi.org/10.1080/13603116.2014.885595 
Purnomo, J. (2014). Penggunaan Media Audio-Visual Pada Mata Pelajaran Ilmu Pengetahuan Alam Di Sekolah Menengah Pertama Negeri [Use of AudioVisual Media in Natural Science Subjects in Public Junior High Schools]. Jurnal Teknologi Pendidikan Dan Pembelajaran.

Putri, S. D., \& Citra, D. E. (2019). Problematika Guru dalam Menggunakan Media Pembelajaran Pada Mata Pelajaran IPS di Madrasah Ibtidaiyah Darussalam Kota Bengkulu [The Problems of Teachers in Using Learning Media in Social Studies Subjects in Madrasah Ibtidaiyah Darussalam, Bengkulu City]. Indonesian Journal of Social Science Education (IJSSE), 1(1), 49-54.

Saripudin, A., \& Faujiah, I. Y. (2018). Strategi Edutainment dalam Pembelajaran di PAUD (Studi Kasus Pada TK di Kota Cirebon) [Edutainment Strategies in Learning in PAUD (Case Study at Kindergarten in Cirebon City)]. AWLADY: Jurnal Pendidikan Anak, 4 (1)(1), 129-149. https://doi.org/10.24235/AWLADY.V4I1.2637

Subaidi, S. (2020). Kepemimpinan Kepala Madrasah Dalam Upaya Meningkatkan Mutu Pendidikan dan Kinerja Guru di MAN 1 Pati [Leadership of the Head of Madrasah in an Effort to Improve the Quality of Education and Teacher Performance in MAN 1 Pati]. Tadbir: Jurnal Studi Manajemen Pendidikan, 4(2), 161-174.

Syaputra, E. (2019). Local Wisdom for Character Education: A Study of Character Values in Tabot Tradition in Bengkulu. Indonesian Journal of Social Science Education (IJSSE), 1(2), 136-144. https://doi.org/10.29300/IJSSE.V1I2.2245

Tanjung, M. A., Azmi, F., \& Siahaan, S. (2017). Headmaster Policy of Senior Islamic School to Increase Teacher Profesionalism at State Senior Islamic School 2 Model Medan. International Journal on Language, Research and Education Studies. https://doi.org/10.30575/2017081210

Tiswarni, T. (2019). Usaha Kepala Sekolah dalam Meningkatkan Disiplin Kerja Guru (Studi Deskriptif Kualitatif di SMP N 1 Argamakmur Kabupaten Bengkulu Utara) [The Principal's Efforts to Improve Teacher Work Discipline (Qualitative Descriptive Study in SMP N 1 Argamakmur, North 
Bengkulu Regency)]. At-Ta'lim: Media Informasi Pendidikan Islam, 18(1), 261. https://doi.org/10.29300/attalim.v18i1.1650

Triwiyanto, T. (2013). Pemetaan Mutu Manajemen Berbasis Sekolah Melalui Audit Manajemen Pendidikan [Mapping the Quality of School-Based Management through the Education Management Audit]. Jurnal Manajemen Pendidikan.

Zulkifli, Z. (2014). Strategi Kepala Sekolah dalam Meningkatkan Kompetensi Profesional Guru Pada SMA Negeri 1 Peukan Bada Kabupaten Aceh Besar [The Principal's Strategy in Improving the Professional Competence of Teachers at SMA Negeri 1 Peukan Bada, Aceh Besar District]. Jurnal Ilmiah Didaktika. https://doi.org/10.22373/jid.v14i2.505 